\title{
Europejski nakaz dochodzeniowy jako kompleksowy instrument współpracy w sprawach karnych w Unii Europejskiej
}

Jedną z form współpracy międzynarodowej w sprawach karnych w zakresie gromadzenia i przekazywania dowodów na terenie Unii Europejskiej jest środek zwany europejskim nakazem dochodzeniowym (END). Kwestię tę reguluje dyrektywa Parlamentu Europejskiego i Rady nr 2014/41/UE $\mathrm{z}$ dnia 3 kwietnia 2014 r. w sprawie europejskiego nakazu dochodzeniowego w sprawach karnych ${ }^{2}$. Dokument ten wprowadził ułatwienia w procesie podejmowania czynności dowodowych za granicą (terytorium Unii Europejskiej), a także przekazywania dowodów już istniejących - zarówno na etapie postępowania przygotowawczego, jak i sądowego. Podstawową zaletą tego środka jest możliwość jego zastosowania $\mathrm{w}$ prawie wszystkich państwach członkowskich Unii Europejskiej. Przedmiotem europejskiego nakazu dochodzeniowego może być ponadto każda czynność dochodzeniowa, bez względu na to, czy została ona wprost wskazana w dyrektywie END ${ }^{4}$.

W niniejszym opracowaniu omówiona zostanie istota, cel i przedmiot END, procedury związane $\mathrm{z}$ jego wydaniem i przekazaniem, a także problemy praktyczne wiążące się z wydaniem europejskiego nakazu dochodzeniowego przez polskie organy ścigania na etapie postępowania przygotowawczego.

Głównym problemem badawczym niniejszego opracowania jest odpowiedź na pytanie o istotę i cel europejskiego nakazu dochodzeniowego w sprawach karnych. Wnikają z niego również problemy cząstkowe, sprowadzające się do odpowiedzi na pytania: co stanowi przedmiot europejskiego nakazu dochodzeniowego? Jak wygląda mechanizm wydawania

1 Mgr Angela Król, doktorantka, Wydział Prawa i Administracji, Uniwersytet Jagielloński.

2 Dz.Urz. UE L 130, s. 1, ze zm., dalej: dyrektywa END.

3 Zgodnie z motywem 44 i 45 preambuły dyrektywy END Irlandia oraz Dania nie uczestniczą w jej przyjęciu.

4 S.R. Buczma, R. Kierzynka, Europejski nakaz dochodzeniowy. Nowy model wspótpracy w sprawach karnych w Unii Europejskiej, Warszawa 2018, s. 7. 
europejskiego nakazu dochodzeniowego i przekazywania go do państwa wykonującego? Jakiego rodzaju problemy pojawiają się podczas występowania $\mathrm{z}$ europejskim nakazem dochodzeniowym przez polskie organy ścigania $\mathrm{w}$ postępowaniu przygotowawczym?

Głównym celem badań jest określenie istoty i celu europejskiego nakazu dochodzeniowego, pojmowanego jako narzędzie walki z przestępczością i terroryzmem na terenie Unii Europejskiej, a także przeanalizowanie procesu związanego z jego wydaniem oraz przekazaniem do wykonania. Ponadto celem niniejszego opracowania jest zidentyfikowanie głównych problemów wiążących się z wydaniem europejskiego nakazu dochodzeniowego przez polskie organy ścigania na etapie postępowania przygotowawczego.

W celu eksplikacji przedstawionych problemów badawczych zastosowana zostanie metoda analizy tekstowej (szeroko rozumianej, w tym analizy formalno-dogmatycznej).

W procesie doboru materiału badawczego brano pod uwagę przedmiot, cel i charakter badań, a także rodzaj oraz treść postawionych problemów badawczych. W pierwszej kolejności ustalono źródła danych o przedmiocie badań, które pozwolą w możliwie najpełniejszy sposób rozwiązać podjęty problem. Za podstawowe źródła wiedzy o europejskim nakazie dochodzeniowym uznano akty prawa pierwotnego, inne akty normatywne i dokumenty wydane przez organy Unii Europejskiej dotyczące END oraz innych instrumentów prawnych z zakresu pomocy prawnej w sprawach karnych, jak również informacje pozyskane z opracowań naukowych.

\section{Geneza europejskiego nakazu dochodzeniowego}

Konieczność utworzenia jednolitych instrumentów współpracy w sprawach karnych w Unii Europejskiej sygnalizowana była od początku jej funkcjonowania. Rozwój współpracy w tym segmencie następował wraz z postępującym procesem integracyjnym oraz równolegle do prac prowadzonych przez Radę Europy ${ }^{5}$. W efekcie doprowadziło to do ustanowienia na mocy Traktatu o Unii Europejskiej ${ }^{6}$ wspólnej przestrzeni wolności, bezpieczeństwa i sprawiedliwości. Traktat ten włączył do polityki unijnej dotychczasowe formy współpracy w zakresie polityki zagranicznej oraz bezpieczeństwa zewnętrznego, a także wewnętrznego ${ }^{7}$. Zapewnienie bezpieczeństwa wewnętrznego stanowi zatem jeden $\mathrm{z}$ fundamentalnych celów integracji europejskiej w kontekście tworzenia na terytorium Unii Europejskiej prze-

5 Ibidem, s. 43.

6 Traktat o Unii Europejskiej, wersja skonsolidowana Dz.Urz. UE z 2016 r. C 202, s. 13.

7 A. Gajda, Polityka bezpieczeństwa wewnętrznego Unii Europejskiej, „Studia z Polityki Publicznej" 2015, nr 3, s. 36-37. 
strzeni wolności, bezpieczeństwa i sprawiedliwości ${ }^{8}$. Szczegółowe regulacje dotyczące tej części polityki wewnętrznej Unii zawiera tytuł V części trzeciej Traktatu o funkcjonowaniu Unii Europejskiej'. Zgodnie z art. 67 ust. 3 TFUE „Unia dokłada starań, aby zapewnić wysoki poziom bezpieczeństwa za pomocą środków zapobiegających przestępczości, rasizmowi i ksenofobii oraz zwalczających te zjawiska, a także za pomocą środków służących koordynacji i współpracy organów policyjnych i sądowych oraz innych właściwych organów, a także za pomocą wzajemnego uznawania orzeczeń sądowych w sprawach karnych i, w miarę potrzeby, przez zbliżanie przepisów karnych”. Natomiast w art. 82 ust. 1 lit. a TFUE wskazano: „Współpraca wymiarów sprawiedliwości w sprawach karnych w Unii opiera się na zasadzie wzajemnego uznawania wyroków i orzeczeń sądowych oraz obejmuje zbliżanie przepisów ustawowych i wykonawczych Państw Członkowskich (...) Parlament Europejski i Rada (...) przyjmują środki mające na celu (...) ustanowienie zasad i procedur zapewniających uznawanie w całej Unii wszystkich form wyroków i orzeczeń sądowych".

Potrzeba ułatwienia procesu gromadzenia materiału dowodowego w przypadku spraw o charakterze transgranicznym i działań w kierunku umożliwienia dopuszczalności takich materiałów w sądzie akcentowana była również $\mathrm{w}$ innych dokumentach wydawanych przez organy Unii Europejskiej.

W październiku 1999 r., podczas posiedzenia Rady Europejskiej w Tampere, jako podstawę współpracy sądowej wskazano zasadę wzajemnego uznawania, a ponadto stwierdzono, że wzmożone wzajemne uznawanie decyzji sądowych i orzeczeń oraz niezbędne zbliżenie prawodawstwa ułatwiłoby współpracę pomiędzy władzami oraz ochronę sądową praw jednostki ${ }^{10}$. Wówczas odniesiono się także do etapu postępowania przygotowawczego, wskazując, że powyższa zasada powinna mieć zastosowanie również do zarządzeń wydanych na tym etapie postępowania karnego, a szczególnie w wypadkach, które pozwoliłyby organom na szybkie zabezpieczenie materiału dowodowego oraz zajęcie majątku ruchomego. Ponadto uznano, że materiał dowodowy zebrany zgodnie z prawem jednego państwa członkowskiego przez jego właściwe organy powinien być dopuszczony w postępowaniu przed sądem innego państwa członkowskiego,

8 I. Kawka, Kompetencje Unii Europejskiej i państw członkowskich w dziedzinie bezpieczeństwa wewnętrznego, „Annales Universitatis Paedagogicae Cracoviensis” Studia Politologica VII. Bezpieczeństwo wewnętrzne państwa 2012, nr 119, s. 45.

9 Traktat o funkcjonowaniu Unii Europejskiej, wersja skonsolidowana Dz.Urz. UE z 2016 r. C 202, s. 47, dalej: TFUE.

10 Posiedzenie Rady Europejskiej w dniach 15-16 października 1999 r. w Tampere, Konkluzje Prezydencji, https://www.consilium.europa.eu/media/21059/tampere-european-council-presidency-conclusions.pdf (dostęp: 1.04.2019). 
oczywiście po uwzględnieniu standardów, które mają zastosowanie w tym właśnie państwie ${ }^{11}$.

W treści postanowień Programu działań na rzecz wdrożenia zasady

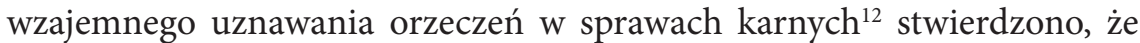
głównym celem nakazów mających pomóc w uzyskiwaniu materiału dowodowego jest zapewnienie jego dopuszczalności, zapobieganie usuwaniu dowodów oraz ułatwienie wprowadzania nakazów przeszukania lub zajęcia, co w konsekwencji umożliwia szybkie zabezpieczenie materiału dowodowego w postępowaniu karnym.

Wśród założeń Programu Haskiego ${ }^{13}$ zawarto postulat wdrożenia szeroko zakrojonego programu środków mających na celu wprowadzenie w życie zasady wzajemnego uznawania orzeczeń w sprawach karnych, obejmującego decyzje sądowe zapadłe na wszystkich etapach procedur karnych.

Kolejnym wartym wzmianki dokumentem jest komunikat Komisji do Parlamentu Europejskiego i Rady „Przestrzeń wolności, bezpieczeństwa i sprawiedliwości w służbie obywateli", w którym przewidziano stworzenie systemu uzyskiwania materiału dowodowego $\mathrm{w}$ sprawach transgranicznych $^{14}$. Wskazano wówczas, że wymagałoby to zastąpienia istniejących już rozwiązań instrumentem pojedynczym, który byłby automatycznie uznawany i stosowany w całej Unii Europejskiej. Takie rozwiązanie mogłoby zachęcić państwa członkowskie do natychmiastowej współpracy. W komunikacie tym podkreślono, że w ramach nowego środka zostałyby wprowadzone terminy jego wykonania oraz ograniczone podstawy odmowy wykonania. Takie narzędzie mogłoby ponadto określać zasady odnoszące się do kategorii dowodów cyfrowych oraz wideokonferencji czy też minimalnych zasad ułatwiających wzajemne dopuszczanie dowodów między państwami członkowskimi, w tym także w zakresie dowodów naukowych.

Komisja Europejska w Zielonej Księdze w sprawie wzajemnego udostępniania przez państwa członkowskie materiału dowodowego $\mathrm{w}$ sprawach karnych oraz zapewnienia jego dopuszczalności z dnia 11 listopada 2009 r. podkreśliła, że jednym z celów UE jest utrzymanie i rozwój przestrzeni wolności, bezpieczeństwa i sprawiedliwości, zwłaszcza poprzez ułatwianie i usprawnianie współpracy sądowej w sprawach karnych po-

11 Ibidem.

12 Program działań na rzecz wdrożenia zasady wzajemnego uznawania orzeczeń w sprawach karnych, Dz.Urz. UE z 2001 r., C 12, cyt. za: S.R. Buczma, R. Kierzynka, Europejski nakaz dochodzeniowy..., s. 146.

13 Program Haski: wzmacnianie wolności, bezpieczeństwa i sprawiedliwości w Unii Europejskiej, Dz.Urz. UE z 2005 r. C 53, s. 1.

14 Komunikat Komisji do Parlamentu Europejskiego i Rady: Przestrzeń wolności, bezpieczeństwa i sprawiedliwości w służbie obywateli, COM (2009) 262 wersja ostateczna, https://eur-lex.europa.eu/legal-content/PL/TXT/?uri=CELEX\%3A52009DC0262 (dostęp: 1.04.2019). 
między państwami członkowskimi ${ }^{15}$. Stwierdzono, że różnice w systemach sądowniczych państw członkowskich nie powinny utrudniać wymierzania sprawiedliwości w kontekście przestępczości transgranicznej, wobec czego szczególne znaczenie ma rozwijanie skutecznej współpracy w kwestiach związanych z uzyskiwaniem materiału dowodowego ${ }^{16}$.

Do czasu wydania dyrektywy Parlamentu Europejskiego i Rady nr 2014/ 41/UE w sprawie europejskiego nakazu dochodzeniowego w sprawach karnych współpraca sądowa między państwami członkowskimi w tego typu sprawach opierała się na instrumentach prawnych dwojakiego rodzaju.

Pierwszy rodzaj stanowiły narzędzia oparte na zasadzie wzajemnej pomocy, a wśród nich uregulowania Europejskiej konwencji o pomocy prawnej w sprawach karnych ${ }^{17}$, układu z Schengen ${ }^{18}$ oraz Konwencji o wzajemnej pomocy w sprawach karnych ${ }^{19}$ wraz z protokołem. Obejmują one ogólne przepisy dotyczące tego rodzaju pomocy prawnej oraz zasady dotyczące jej konkretnych form, takich jak przechwytywanie informacji w sieciach telekomunikacyjnych lub użycie systemów wideokonferencji ${ }^{20}$. Wnioski o udzielenie pomocy prawnej oparte na wymienionych uregulowaniach przekazywano co do zasady bezpośrednio pomiędzy organem wydającym a organem wykonującym. Strona wezwana (organ państwa, do którego zwrócono się o udzielenie pomocy prawnej) powinna spełnić wskazane przez stronę wzywającą (organ zwracający się o udzielenie pomocy prawnej) wymogi formalne, które zapewniają dopuszczalność uzyskanego materiału dowodowego $\mathrm{w}$ procesie, o ile nie sprzeciwia się temu prawo strony wezwanej. Opisane środki nie przewidują obowiązku korzystania ze standardowego formularza $\mathrm{w}$ przypadku zwrócenia się z wnioskiem o pomoc $\mathrm{w}$ uzyskaniu materiału dowodowego zlokalizowanego w innym państwie, a ponadto nie określają terminu, w którym ta pomoc miałaby zostać udzielona przez stronę wezwaną.

Drugą kategorię środków służących do uzyskiwania materiału dowodowego w sprawach karnych, stanowiły narzędzia oparte na zasadzie wzajemnego uznawania, a wśród nich środek przyjęty w decyzji ramowej w spra-

15 Zielona Księga z dnia 11 listopada 2009 r. w sprawie wzajemnego udostępniania przez państwa członkowskie materiału dowodowego w sprawach karnych oraz zapewnienia jego dopuszczalności, KOM (2009) 624 wersja ostateczna, https://eur-lex.europa. eu/LexUriServ/LexUriServ.do?uri=COM:2009:0624:FIN:PL:PDF (dostęp: 1.04.2019).

16 Ibidem.

17 Europejska konwencja o pomocy prawnej w sprawach karnych z 20 kwietnia 1959 r., Dz.U. z 1999 r. Nr 76, poz. 854 ze zm.

18 Konwencja wykonawcza do układu z Schengen z dnia 14 czerwca 1985 r. między Rządami Państw Unii Gospodarczej Beneluksu, Republiki Federalnej Niemiec oraz Republiki Francuskiej w sprawie stopniowego znoszenia kontroli na wspólnych granicach, Dz.Urz. WE z 2000 r. L 239, s. 19, ze zm.

19 Konwencja o wzajemnej pomocy w sprawach karnych między państwami członkowskimi Unii Europejskiej, Dz.U. z 1998 r. Nr 141, poz. 913 ze zm.

20 S.R. Buczma, R. Kierzynka, Europejski nakaz dochodzeniowy..., s. 147-148. 
wie europejskiego nakazu dowodowego ${ }^{21}$. Kolejnym rozwiązaniem były unormowania zawarte w decyzji ramowej w sprawie wykonania w Unii Europejskiej postanowień o zabezpieczeniu mienia i środków dowodowych ${ }^{22}$, których zakres ograniczono do zabezpieczania dowodów w innym państwie członkowskim. Ewentualne późniejsze przekazanie dowodów pomiędzy odpowiednimi państwami członkowskimi podlegało regulacji opartej na zasadzie wzajemnej pomocy lub decyzji ramowej w sprawie europejskiego nakazu dowodowego. Europejski nakaz dowodowy wydawany był $\mathrm{w}$ postaci standardowego dokumentu, a następnie tłumaczony na oficjalny język państwa wykonującego. Organy wydające były zobowiązane stwierdzić m.in., że materiał dowodowy, którego dotyczy europejski nakaz dowodowy, jest niezbędny i proporcjonalny w stosunku do celów postępowania, w którym zostaje wydany. Również w przypadku tego środka organy państwa wykonującego zobowiązane zostały do spełnienia wymogów formalnych wskazanych przez organy państwa wydającego, zapewniających dopuszczalność uzyskanego materiału dowodowego w procesie. Standardy te były zachowywane przez państwo wykonujące, jeżeli nie stały w sprzeczności z podstawowymi zasadami prawa obowiązującymi na jego terytorium.

Powyższy nakaz był wydawany w celu uzyskania istniejącego materiału dowodowego, bezpośrednio dostępnego w postaci przedmiotów, dokumentów lub danych ${ }^{23}$, a więc spod jego zakresu wyłączona została możliwość uzyskania materiału dowodowego bezpośrednio dostępnego, ale nieistniejącego, jak np. przesłuchanie świadka czy podejrzanego, a także uzyskanie informacji w czasie rzeczywistym (przechwytywanie informacji w sieci telekomunikacyjnej lub monitorowanie rachunków bankowych), które mimo bezpośredniej dostępności jeszcze nie istnieją ${ }^{24}$, bowiem nie zostały w odpowiedni sposób przetworzone.

System uzyskiwania materiału dowodowego składał się zatem $\mathrm{z}$ wielu współistniejących instrumentów, które oparte były na różnych zasadach, tj. zasadzie wzajemnej pomocy oraz zasadzie wzajemnego uznawania. W przywołanej wyżej Zielonej Księdze w sprawie wzajemnego udostępniania przez państwa członkowskie materiału dowodowego w sprawach karnych zauważono, że tak złożony system nie przyczynia się do usprawnienia i uskutecznienia procesu pozyskiwania dowodów w sprawach transgra-

21 Decyzja ramowa Rady 2008/978/WSiSW z dnia 18 grudnia 2008 r. w sprawie europejskiego nakazu dowodowego dotyczącego przedmiotów, dokumentów i danych, które mają zostać wykorzystane w postępowaniach w sprawach karnych, Dz.Urz. UE L 350, s. 72.

22 Decyzja ramowa Rady 2003/577/WSiSW z dnia 22 lipca 2003 r. w sprawie wykonania w Unii Europejskiej postanowień o zabezpieczeniu mienia i środków dowodowych, Dz.Urz. UE L 196, s. 45.

23 Zielona Księga z dnia 11 listopada 2009 r. w sprawie wzajemnego udostępniania przez państwa członkowskie materiału dowodowego w sprawach karnych.

24 Ibidem. 
nicznych, a wręcz może wpływać nań negatywnie. W efekcie może bowiem doprowadzić do sytuacji, w których dla pozyskania określonego rodzaju dowodu nie zostaną wykorzystane najbardziej właściwe dla niego środki ${ }^{25}$. W Księdze zawarto postulat zastąpienia istniejących, fragmentarycznych ram prawnych jednolitym rozwiązaniem, które byłoby oparte na zasadzie wzajemnego uznawania, obejmującym wszystkie rodzaje materiału dowodowego ${ }^{26}$, również opisany powyżej materiał bezpośrednio dostępny, ale nieistniejący oraz materiał istniejący, ale bezpośrednio niedostępnego (np. uzyskanie materiału biologicznego w postaci DNA czy też analiza danych).

Komisja Europejska, mając na względzie wszystkie przytoczone powyżej uwagi, zwróciła się do państw członkowskich z pytaniami dotyczącymi kwestii wprowadzenia jednolitego instrumentu oraz zajęcia przez państwa członkowskie stanowiska $\mathrm{w}$ tym zakresie. Przeprowadzone konsultacje pozwoliły ustalić, że większość państw członkowskich popiera koncepcję zastąpienia dotychczasowych uregulowań jednym instrumentem, który powinien cechować się elastycznością, a jednocześnie pewnym automatyzmem procedowania ${ }^{27}$.

W efekcie, z inicjatywy Królestwa Belgii, Republiki Bułgarii, Republiki Estońskiej, Królestwa Hiszpanii, Republiki Austrii, Republiki Słowenii i Królestwa Szwecji, sporządzono projekt instrumentu w sprawie europejskiego nakazu dochodzeniowego ${ }^{28}$. Ostatecznie w dniu 3 kwietnia $2014 \mathrm{r}$. przyjęto dyrektywę Parlamentu Europejskiego i Rady nr 2014/41/UE w sprawie europejskiego nakazu dochodzeniowego w sprawach karnych.

\section{Europejski nakaz dochodzeniowy - istota i cel}

Na tle przeprowadzonych powyżej rozważań należy uznać, że dyrektywa nr 2014/41/UE w sprawie europejskiego nakazu dochodzeniowego w sprawach karnych przyjęta została w celu ujednolicenia i usprawnienia systemu pozyskiwania dowodów $\mathrm{w}$ sprawach o charakterze transgranicznym.

W rozbudowanej preambule tego aktu normatywnego w pierwszej kolejności przytoczono zasadę wzajemnego uznawania wyroków i orzeczeń sądowych, która „od czasu posiedzenia Rady Europejskiej w Tampere w dniach 15-16 października 1999 r. powszechnie określana [jest - przyp. A.K.] kamieniem węgielnym współpracy wymiarów sprawiedliwości w sprawach karnych w Unii”"

W dalszej części preambuły wskazano na niekompletność, rozdrobnienie oraz skomplikowany charakter dotychczasowych uregulowań i po-

25 S.R. Buczma, R. Kierzynka, Europejski nakaz dochodzeniowy..., s. 149.

26 Zielona Księga z dnia 11 listopada 2009 r. w sprawie wzajemnego udostępniania przez państwa członkowskie materiału dowodowego w sprawach karnych.

27 S.R. Buczma, R. Kierzynka, Europejski nakaz dochodzeniowy..., s. 154.

28 Procedura 2010/0817/COD przyjęcia dyrektywy nr 2014/41/UE, https://eur-lex.europa.eu/legal-content/PL/HIS/?uri=CELEX:32014L0041 (dostęp: 30.04.2019). 
trzebę zastąpienia ich kompleksowym systemem, który w jak najszerszym zakresie objąłby wszystkie rodzaje dowodów, przewidywałby termin wykonania i maksymalnie ograniczał podstawy odmowy. Osiągnięciu powyższych celów ma służyć europejski nakaz dochodzeniowy.

Ten nowy model transgranicznego pozyskiwania dowodów stosowany jest w celu wezwania właściwych organów państwa wykonującego END do przeprowadzenia na jego terytorium jednej lub więcej określonych czynności dochodzeniowych, służących gromadzeniu materiału dowodowego na każdym etapie postępowania karnego. W preambule dyrektywy END podkreślono, że instrument ten obejmuje również czynności polegające na pozyskaniu materiału dowodowego, którym organ wykonujący już dysponuje. Europejski nakaz dochodzeniowy ma zatem wymiar horyzontalny, bowiem dotyczy wszystkich czynności dochodzeniowych mających na celu gromadzenie materiału dowodowego.

Jednakże w preambule zawarto pewne wyłączenia zakresu obowiązywania tego środka, nie objęto nim bowiem obserwacji transgranicznej, a w odniesieniu do czynności polegających na utworzeniu wspólnych zespołów dochodzeniowo-śledczych czy też gromadzeniu materiału dowodowego w ramach takich zespołów postanowiono stosować odrębne przepisy bez uszczerbku dla nowoutworzonego instrumentu. Rozwiązanie to zostało powtórzone w art. 3 dyrektywy END.

W preambule dyrektywy END odniesiono się ponadto do niektórych szczególnych czynności dowodowych, tj. tymczasowego przekazania osób pozbawionych wolności, przesłuchania metodą tele- lub wideokonferencji, uzyskiwania informacji o rachunkach lub operacjach bankowych czy stosowania przesyłek niejawnie nadzorowanych lub dochodzeń niejawnych, wskazując, że wymagają one dodatkowych regulacji. Natomiast w odniesieniu do czynności polegających na bieżącym, stałym lub czasowym gromadzeniu materiału dowodowego, które mogą być objęte europejskim nakazem dochodzeniowym, przewidziano możliwość dokonywania pomiędzy stronami praktycznych uzgodnień w celu uwzględnienia różnic w krajowych systemach prawnych państw członkowskich. Szczegółowe uregulowania w tym zakresie zostały zawarte w rozdziale IV dyrektywy END.

$\mathrm{W}$ preambule dyrektywy wskazano również, że powinna ona być wykonywana przy jednoczesnym uwzględnieniu dyrektyw 2010/64/UE ${ }^{29}$, 2012/13/UE ${ }^{30}$ oraz 2013/48/UE ${ }^{31}$ Parlamentu Europejskiego i Rady. Dy-

29 Dyrektywa Parlamentu Europejskiego i Rady 2010/64/UE z dnia 20 października 2010 r. w sprawie prawa do tłumaczenia ustnego i tłumaczenia pisemnego w postępowaniu karnym, Dz.Urz. UE L 280, s. 1.

30 Dyrektywa Parlamentu Europejskiego i Rady 2012/13/UE z dnia 22 maja 2012 r. w sprawie prawa do informacji w postępowaniu karnym, Dz.Urz. UE L 142, s. 1.

31 Dyrektywa Parlamentu Europejskiego i Rady 2013/48/UE z dnia 22 października 2013 r. w sprawie prawa dostępu do adwokata w postępowaniu karnym i w postępowaniu dotyczącym europejskiego nakazu aresztowania oraz $\mathrm{w}$ sprawie prawa do po- 
rektywy te dotyczą praw przysługujących w postępowaniu karnym podejrzanemu, oskarżonemu oraz osobie objętej postępowaniem w przedmiocie europejskiego nakazu aresztowania.

Zgodnie z treścią art. 34 dyrektywy END zastępuje ona dotychczasowe postanowienia regulujące stosunki między państwami członkowskimi w zakresie pomocy prawnej w sprawach karnych, bez uszczerbku dla ich stosowania między państwami członkowskimi a państwami trzecimi oraz dla ich tymczasowego stosowania, tj.:

a) Europejską konwencję o pomocy prawnej w sprawach karnych Rady Europy z dnia 20 kwietnia 1959 r., dwa protokoły dodatkowe do niej oraz porozumienia dwustronne zawarte zgodnie z jej art. 26,

b) Konwencję wykonawczą do układu z Schengen,

c) Konwencję o pomocy prawnej w sprawach karnych pomiędzy państwami członkowskimi Unii Europejskiej i protokół do niej,

d) decyzję ramową 2008/978/WSiSW w sprawie europejskiego nakazu dowodowego ${ }^{32}$

e) decyzję ramową 2003/577/WSiSW w sprawie wykonania w Unii Europejskiej postanowień o zabezpieczeniu mienia i środków dowodowych w zakresie zabezpieczenia dowodów (co oznacza, że pozostaje ona w mocy w zakresie zabezpieczenia mienia).

Powyższe akty prawne zostały zastąpione dyrektywą END tylko w odniesieniu do państw członkowskich, które są nią związane ${ }^{33}$. Ponadto państwa członkowskie mogą - po dokonaniu implementacji dyrektywy w dalszym ciągu stosować lub zawierać między sobą dwustronne i wielostronne porozumienia odnoszące się do jej materii, o ile umożliwiają one wzmocnienie jej celów i przyczyniają się do uproszczenia czy też ułatwienia procedur gromadzenia materiału dowodowego, przy zapewnieniu poziomu gwarancji określonego w dyrektywie END.

\section{Zakres stosowania i przedmiot europejskiego nakazu dochodzeniowego}

Zgodnie z treścią art. 1 dyrektywy END europejski nakaz dochodzeniowy ma postać orzeczenia sądowego wydanego lub zatwierdzonego przez

informowania osoby trzeciej o pozbawieniu wolności i prawa do porozumiewania się z osobami trzecimi i organami konsularnymi w czasie pozbawienia wolności, Dz.Urz. UE L 294, s. 1.

32 Decyzja ramowa 2008/978/WSiSW w sprawie europejskiego nakazu dowodowego została ostatecznie uchylona rozporządzeniem Parlamentu Europejskiego i Rady (UE) nr 2016/95 z dnia 20 stycznia 2016 r. w sprawie uchylenia niektórych aktów w dziedzinie współpracy policyjnej i współpracy wymiarów sprawiedliwości w sprawach karnych, Dz.Urz. UE L 26, s. 9.

33 Współpraca w zakresie pomocy prawnej w sprawach karnych pomiędzy państwami członkowskimi a Irlandią oraz Danią, które nie uczestniczą w przyjęciu dyrektywy END, opiera się na dotychczasowych uregulowaniach w tym zakresie. 
organ wymiaru sprawiedliwości jednego państwa członkowskiego (państwo wydające) w celu wezwania innego państwa członkowskiego (państwo wykonujące) do przeprowadzenia jednej lub kilku określonych czynności dochodzeniowych. Celem tego środka jest zatem uzyskanie materiału dowodowego, z pewnymi włączeniami, o czym była mowa wyżej. Dokument ten przybiera formę formularza, którego wzór stanowi załącznik A do dyrektywy END.

Wskazane w art. 1 dyrektywy pojęcie orzeczenia sądowego należy rozumieć szeroko nie tylko w kontekście organu, który uprawniony jest do wydania europejskiego nakazu dochodzeniowego. W nomenklaturze europejskiej przez pojęcie organu sądowego rozumie się sąd, sędziego oraz prokuratora ${ }^{34}$. Zgodnie $\mathrm{z}$ takim sposobem pojmowania organu sądowego orzeczeniem sądowym $\mathrm{w}$ rozumieniu omawianej dyrektywy jest nie tylko orzeczenie wydane przez sąd czy sędziego, lecz także decyzja wydana przez prokuratora. Na przyjęcie takiego stanowiska pozwalają również uregulowania dyrektywy END, które dotyczą uprawnienia do wydania i zatwierdzenia tego środka.

Organem uprawnionym do wydania END jest - zgodnie z treścią art. 2 lit. c dyrektywy END - sędzia, sąd, sędzia śledczy lub prokurator właściwy $\mathrm{w}$ danej sprawie. Ponadto uprawnienie takie posiada każdy inny właściwy organ określony przez państwo wydające, który pełni w danym przypadku funkcję organu dochodzeniowego w postępowaniu karnym, a więc organ władny do tego, by nakazać gromadzenie materiału dowodowego zgodnie $\mathrm{z}$ prawem krajowym. W tym ostatnim wypadku END wydany przez taki organ wymaga zatwierdzenia przez organ wymiaru sprawiedliwości, tj. sędziego, sąd, sędziego śledczego czy prokuratora w państwie wydającym.

Zgodnie $\mathrm{z}$ art. 1 ust. 3 dyrektywy END wskazane organy mogą skorzystać z opisywanego instrumentu, działając z urzędu bądź na wniosek podejrzanego, oskarżonego lub prawnika reprezentującego prawa takiej osoby w procesie ${ }^{35}$.

Dyrektywa END nakłada na organ wydający pewne ograniczenia, bowiem zgodnie $\mathrm{z}$ motywem 11 preambuły europejski nakaz dowodowy może być zastosowany, jeżeli przeprowadzenie określonej czynności dochodzeniowej będzie proporcjonalne, odpowiednie i mające zastosowanie do danej sprawy. Wymaga to przeprowadzenia oceny i ustalenia przez ten organ, czy:

34 S.R. Buczma, R. Kierzynka, Europejski nakaz dochodzeniowy..., s. 163.

35 Kwestia ta w polskim porządku prawnym została uregulowana w szerszym zakresie, gdyż zgodnie z art. 589 w ustawy z dnia 6 czerwca 1997 r. - Kodeks postępowania karnego (tekst jedn.: Dz.U. z 2018 r. poz. 1987 ze zm., dalej: k.p.k.) do złożenia takiego wniosku uprawnione są strony postępowania, a więc podejrzany, oskarżony i jego obrońca oraz pokrzywdzony i jego pełnomocnik. 
- żądany materiał dowodowy jest konieczny i proporcjonalny do celów postępowania,

- wybrana czynność dochodzeniowa jest konieczna i proporcjonalna do jego gromadzenia,

- poprzez wydanie END należy zaangażować w gromadzenie tego materiału dowodowego inne państwo członkowskie.

Taka sama procedura została przewidziana $\mathrm{w}$ ramach czynności zatwierdzania END przez organ sądowy, jeżeli europejski nakaz dochodzeniowy został wydany przez inny organ.

Organ wykonujący europejski nakaz dochodzeniowy został z kolei wyposażony w uprawnienie do przeprowadzenia czynności dochodzeniowej innego rodzaju niż czynność wskazana w END w określonych przypadkach, tj.:

- jeśli przeprowadzenie takiego dowodu byłoby niedopuszczalne w podobnej sprawie krajowej lub

- czynność taka nie została przewidziana w obowiązującym prawie państwa wykonującego, lub

- czynność dochodzeniowa innego rodzaju doprowadzi do takiego samego rezultatu, ale w mniejszym stopniu będzie ingerować w prawa podstawowe danej osoby.

Jak już wskazano wyżej, przedmiotem europejskiego nakazu dochodzeniowego może być - co do zasady - każda czynność dochodzeniowa. Zakres dyrektywy END obejmuje zatem wyłącznie środki dochodzeniowe. Dotychczasowe instrumenty dotyczące tego rodzaju pomocy prawnej regulowały również inne czynności związane z pomocą sądową, jak np. doręczanie pism i dokumentów ${ }^{36}$. Takie czynności, które nie mają charakteru dochodzeniowego, powinny być realizowane według dotychczasowych reguł, bowiem dyrektywa END nie ma do nich zastosowania.

Pewnym wyłączeniom podlegają opisane powyżej wspólne zespoły dochodzeniowo śledcze oraz gromadzenie materiału dowodowego w ramach takiego zespołu, którego utworzenie przewidują przepisy Konwencji ustanowionej przez Radę zgodnie z art. 34 Traktatu o Unii Europejskiej o pomocy prawnej w sprawach karnych między państwami członkowskimi Unii Europejskiej ${ }^{37}$ oraz decyzji ramowej Rady z dnia 13 czerwca 2002 r. w sprawie wspólnych zespołów dochodzeniowo-śledczych (2002/465/WSiSW) ${ }^{38}$. Wyjątek taki został przewidziany w art. 3 dyrektywy END. Wynika to w szczególności z charakteru takich zespołów, bowiem tworzone są one na zasadzie wzajemnych i dobrowolnych uzgodnień między państwami ${ }^{39}$. Zgodnie z treścią przywołanego przepisu wyłączenie to nie dotyczy po-

36 S.R. Buczma, R. Kierzynka, Europejski nakaz dochodzeniowy..., s. 167.

37 Dz.Urz. UE z 2000 r. L 197, s. 3, ze zm.

38 Dz.Urz. UE L 162, s. 1.

39 S.R. Buczma, R. Kierzynka, Europejski nakaz dochodzeniowy..., s. 166. 
dejmowania czynności w celu zastosowania art. 13 ust. 8 konwencji ${ }^{40}$ oraz art. 1 ust. 8 decyzji ramowej 2002/465/WSiSW ${ }^{41}$, na podstawie których możliwe jest wystąpienie zespołu dochodzeniowo-śledczego $\mathrm{z}$ wnioskiem o udzielenie pomocy prawnej do państwa członkowskiego, które nie uczestniczy w jego pracach.

Kolejnym wyłączeniem objęte są czynności polegające na obserwacji transgranicznej, przewidziane w art. 40 Konwencji wykonawczej do układu z Schengen. Wyjątek ten wynika z motywu 9 preambuły dyrektywy END, co może wzbudzać pewne wątpliwości. Zgodnie bowiem z generalną zasadą dyrektywa ta ma zastosowanie do każdej czynność dochodzeniowej, także do czynności wymagających gromadzenia materiału dowodowego w tzw. czasie rzeczywistym, a więc na bieżąco, w sposób ciągły i przez konkretny okres ${ }^{42}$. Katalog ten może zatem obejmować obserwację transgraniczną, która dokonywana będzie na terytorium państwa wykonującego, ale pod warunkiem, że nie będzie przeprowadzana i regulowana przez art. 40 wspomnianej konwencji. Sposób wykonania takiej czynności będzie zatem podlegał zasadom wynikającym z prawa państwa wykonującego oraz omawianej dyrektywy, a nie Konwencji wykonawczej do układu z Schengen ${ }^{43}$.

\section{Procedura wydania i przekazania europejskiego nakazu dochodzeniowego}

W art. 6 i 7 dyrektywy END określone zostały wstępne warunki wydania i przekazania europejskiego nakazu dochodzeniowego. Opisywany instrument może być wydany jedynie wtedy, gdy jest niezbędny dla osiągnięcia celów postępowania, tzn. dowody przeprowadzane na jego podstawie mają rzeczywiste znaczenie dla rozstrzygnięcia sprawy ${ }^{44}$, a także względem nich proporcjonalny. Ten ostatni warunek należy rozumieć szeroko, bowiem w jego zakresie zawiera się zarówno test przydatności dowodu, a więc ocena jego skuteczności dla potwierdzenia tezy dowodowej, a także ocena,

40 Art. 13 ust. 8 konwencji stanowi: „W przypadku gdy wspólny zespół śledczy potrzebuje pomocy ze strony państwa członkowskiego innego niż państwa, które utworzyły zespół, lub ze strony państwa trzeciego, wniosek o pomoc może zostać złożony przez właściwe organy państwa, w którym zespół działa do właściwych organów danego państwa, zgodnie z odpowiednimi instrumentami prawnymi lub uzgodnieniami".

41 Art. 1 ust. 8 decyzji ramowej stanowi: „W przypadku gdy wspólny zespół dochodzeniowo-śledczy zgłasza potrzebę pomocy ze strony Państwa Członkowskiego, które nie uczestniczy w tworzeniu zespołu, lub państwa trzeciego, z wnioskiem o pomoc do właściwych organów tego Państwa, zgodnie z odpowiednimi instrumentami lub uzgodnieniami, występują właściwe organy Państwa Członkowskiego, na terytorium którego zespół prowadzi działania”.

42 S.R. Buczma, R. Kierzynka, Europejski nakaz dochodzeniowy..., s. 166.

43 Ibidem.

44 M. Kusak, Europejski Nakaz Dochodzeniowy w praktyce, LEX nr 335832; idem, Europejski nakaz dochodzeniowy - przełom $w$ dziedzinie europejskiego ścigania karnego?, „Ruch Prawniczy, Ekonomiczny i Socjologiczny” 2012, z. 4. 
czy uzyskany w ten sposób dowód pozostaje w proporcji do skutków, które wynikają $\mathrm{z}$ jego przeprowadzenia ${ }^{45}$. Dla weryfikacji proporcjonalności END istotne znaczenie mają również koszty związane z przeprowadzeniem czynności dowodowej.

Możliwość wydania europejskiego nakazu dochodzeniowego uwarunkowana jest też wymogiem poszanowania praw przysługujących podejrzanemu i oskarżanemu. Wprawdzie opisywana dyrektywa nie wymienia $\mathrm{w}$ tym względzie innych stron postępowania, jednak należałoby $\mathrm{w}$ toku wydawania END rozważyć również usprawiedliwione interesy pozostałych stron $^{46}$.

Kolejnym warunkiem wydania omawianego instrumentu jest dopuszczalność przeprowadzenia żądanej czynności dochodzeniowej w podobnej sprawie krajowej. Organ wydający END nie może zatem żądać przeprowadzenia dowodu, którego nie mógłby przeprowadzić w swojej jurysdykcji w toku podobnej sprawy karnej i w podobnych okolicznościach. Warunek ten dotyczy także sposobu i warunków przeprowadzenia dowodu.

Organ wydający ocenia, czy wskazane powyżej warunki zostały spełnione. Natomiast zgodnie z art. 6 ust. 2 dyrektywy END organ wykonujący jest władny, by w razie powzięcia wątpliwości co do spełnienia któregokolwiek $\mathrm{z}$ wymienionych warunków przeprowadzić z organem wydającym konsultację w sprawie celowości wykonania END. Po dokonaniu takich ustaleń organ wydający może podjąć decyzję o wycofaniu nakazu, natomiast organ wykonujący, poza zainicjowaniem konsultacji, nie posiada żadnych innych skutecznych środków w przypadku niespełnienia opisanych kryteriów.

Po przeprowadzeniu oceny skutkującej uznaniem, że powyższe warunki zostały spełnione, organ wydający europejski nakaz dochodzeniowy przekazuje go - co do zasady - bezpośrednio organowi wykonującemu. Przekazanie odbywa się przy wykorzystaniu dowolnej metody, która pozwoli uzyskać pisemne potwierdzenie autentyczności nakazu. Dalsza komunikacja następuje bezpośrednio pomiędzy zaangażowanymi organami.

Należy jednak pamiętać, że dyrektywa END przyznaje państwom członkowskim uprawnienie do wyznaczenia jednego organu centralnego (lub większej ich liczby), którego zadaniem jest pełnienie funkcji pomocniczych. Państwa członkowskie mogą również powierzyć takim organom centralnym zadanie urzędowego przekazywania i odbioru europejskich nakazów dochodzeniowych oraz prowadzenia dalszej korespondencji urzędowej dotyczącej END. Powołanie takiego organu nie może jednak skutkować zróżnicowaniem kompetencji dowodowych i właściwości organów wykonujących te kompetencje, bowiem w każdym przypadku organem wykonującym europejski nakaz dochodzeniowy powinien być organ uprawniony

45 S.R. Buczma, R. Kierzynka, Europejski nakaz dochodzeniowy..., s. 175.

46 G. Krzysztofiuk, Europejski Nakaz Dochodzeniowy, LEX nr 277538; S.R. Buczma, R. Kierzynka, Europejski nakaz dochodzeniowy..., s. 175. 
do zapewnienia przeprowadzenia określonego dowodu w podobnej sprawie krajowej $^{47}$.

Przekazanie END do właściwego organu wykonującego może nastąpić za pośrednictwem systemu telekomunikacyjnego Europejskiej Sieci Sądowej (ang. European Judicial Network - EJN). W przypadku problemów z określeniem właściwego organu wykonującego punkty kontaktowe EJN są obowiązane do pomocy organom wydającym nakaz w ustaleniu takiego organu. W sytuacji przekazania END organowi wykonującemu, który nie jest właściwy do jego uznania lub wykonania, organ ten przekazuje z urzędu nakaz organowi właściwemu oraz niezwłocznie przesyła stosowną informuję organowi wydającemu.

W art. 8 dyrektywy END została również przewidziana możliwość uzupełnienia wydanego i przekazanego nakazu dochodzeniowego kolejnym END. Taki uzupełniający europejski nakaz dochodzeniowy musi spełniać wszystkie kryteria i warunki formalne przewidziane dla END. Jednakże $\mathrm{w}$ przypadku wydania takiego nakazu $\mathrm{w}$ celu udzielenia pomocy $\mathrm{w}$ wykonaniu wcześniejszego END w państwie wykonującym, organ wydający może go przekazać bezpośrednio do współpracującego organu wykonującego, pomimo powołania w tym państwie pomocniczych organów centralnych, których zadaniem jest przekazywanie tego rodzaju instrumentów.

\section{Problemy praktyczne związane z wydaniem europejskiego nakazu dochodzeniowego w toku postępowania przygotowawczego na gruncie Kodeksu postępowania karnego}

Rozdziały 62c i 62d Kodeksu postępowania karnego, obowiązujące od 8 lutego 2018 r., są wynikiem transpozycji dyrektywy nr 2014/41/UE w sprawie europejskiego nakazu dochodzeniowego w sprawach karnych. Wprowadzają one do polskiego porządku prawnego procedurę wystąpienia z nakazem dochodzeniowym do innych państw członkowskich oraz wykonania w Polsce nakazu wydanego przez właściwe organy innych państw.

W Kodeksie nie przedstawiono szczegółowych, pozytywnych przesłanek wydania nakazu, bowiem $\mathrm{w}$ art. 589w $₫ 1$ posłużono się ogólnym sformułowaniem „W razie konieczności”. Ustawodawca określił jednak przesłanki negatywne, wskazując w art. 589x k.p.k., że wydanie europejskiego nakazu dochodzeniowego jest niedopuszczalne, jeśli nie wymaga tego interes wymiaru sprawiedliwości, a także jeśli w polskim porządku prawnym nie dopuszcza się przeprowadzenia lub uzyskania żądanego dowodu. Zgodnie ze stanowiskiem funkcjonującym $\mathrm{w}$ doktrynie klauzula interesu wymiaru sprawiedliwości powinna uwzględniać proporcjonalność wydania nakazu i celowość zaangażowania organów państw członkowskich, a nadto koszty

47 S.R. Buczma, R. Kierzynka, Europejski nakaz dochodzeniowy..., s. 176. 
jego wykonania ${ }^{48}$. Uregulowanie to stanowi zatem pełne przeniesienie do polskiego porządku prawnego warunków wydania END określonych w dyrektywie nr 2014/41/UE.

Europejski nakaz dochodzeniowy może być wydany zarówno na etapie postępowania przygotowawczego, $\mathrm{w}$ tym postępowania sprawdzającego, jak i na etapie postępowania sądowego (art. 589w $\$ 1$ i 2 k.p.k.). Jego wydanie poprzedzone jest sporządzeniem przez stosowny organ postanowienia $\mathrm{w}$ przedmiocie wydania europejskiego nakazu dochodzeniowego.

$\mathrm{W}$ toku postępowania przygotowawczego organami właściwymi do wydania END są:

1) prokurator prowadzący postępowanie;

2) Policja lub organy, o których mowa w art. 312 k.p.k., tj. Straż Graniczna, Agencja Bezpieczeństwa Wewnętrznego, Krajowa Administracja Skarbowa, Centralne Biuro Antykorupcyjne oraz Żandarmeria Wojskowa w zakresie ich właściwości oraz inne organy przewidziane w przepisach szczególnych;

3) organy uprawnione do prowadzenia postępowań przygotowawczych w sprawach karnych skarbowych określone w art. $133 \$ 1$ i art. $134 \$ 1$ ustawy z dnia 10 września 1999 r. - Kodeks karny skarbowy ${ }^{49}$.

Zgodnie $\mathrm{z}$ art. 589w $\$ 2$ k.p.k. europejski nakaz dochodzeniowy wydany przez organy wskazane w pkt 2-3 wymaga zatwierdzenia przez prokuratora.

Europejski nakaz dochodzeniowy na etapie postępowania sądowego może wydać sąd, przed którym sprawa się toczy.

Nakaz może być wydany również w toku prowadzenia czynności operacyjno-rozpoznawczych. Wówczas organem uprawnionym do jego wydania jest organ prowadzący takie czynności, po uprzednim uzgodnieniu $\mathrm{z}$ organem państwa wykonania orzeczenia czasu trwania oraz warunków wykonywania takich czynności. Wydanie takiego END wymaga zatwierdzenia przez prokuratora, chyba że dopuszczenie, uzyskanie lub przeprowadzenie dowodu jest zastrzeżone do właściwości sądu. Wówczas wydanie END wymaga zatwierdzenia przez właściwy sąd.

Zgodnie $\mathrm{z}$ art. 589w $\$ 5$ k.p.k. postanowienie w przedmiocie wydania END dotyczącego dowodu, którego dopuszczenie, uzyskanie lub przeprowadzenie wymaga wydania postanowienia, zastępuje to postanowienie. Dotyczy to m.in. postanowienia o przeszukaniu, zatrzymaniu rzeczy, wydaniu korespondencji, dopuszczeniu dowodu z opinii biegłego. Wówczas należy odpowiednio zastosować przepisy dotyczące poszczególnych czyn-

48 M. Kusak, Europejski Nakaz Dochodzeniowy w praktyce...; M. Janicz [w:] Kodeks postępowania karnego. Komentarz, LEX nr 10800.

49 Tekst jedn.: Dz.U. z 2018 poz. 1958 ze zm. Zgodnie z treścią przytoczonych przepisów organami prowadzącymi postępowanie przygotowawcze $\mathrm{w}$ określonej w tych przepisach kategorii przestępstw i wykroczeń skarbowych są m.in. naczelnik urzędu celnoskarbowego, naczelnik urzędu skarbowego, Szef Krajowej Administracji Skarbowej. 
ności i dowodów. Wystarczające będzie zatem wydanie jednego postanowienia, to znaczy postanowienia w przedmiocie wydania END w związku $\mathrm{z}$ daną czynnością dowodową̧ ${ }^{50}$. Jeśli natomiast przeprowadzenie żądanej czynności dochodzeniowej wymaga uprzedniego wydania odrębnego postanowienia (np. przesłuchanie w charakterze świadka osoby zobowiązanej do zachowania tajemnicy związanej z wykonywaniem zawodu lub funkcji, które wymaga - zgodnie z treścią art. $180 \$ 1$ k.p.k. - uprzedniego wydania postanowienia $\mathrm{w}$ przedmiocie zwolnienia takiej osoby $\mathrm{z}$ zachowania określonej tajemnicy), to kwestia ta może być zawarta w treści postanowienia o wydaniu END ${ }^{51}$ w odrębnym punkcie.

Problemy praktyczne związane $\mathrm{z}$ wydaniem europejskiego nakazu dochodzeniowego dotyczą w głównej mierze dowodów, których uzyskanie, dopuszczenie lub przeprowadzenie $\mathrm{w}$ postępowaniu przygotowawczym wymaga uprzedniej decyzji nie prokuratora prowadzącego postępowanie, lecz sądu. Przykładem tego rodzaju czynności jest dostęp do informacji, których uzyskanie na tym etapie postępowania karnego uzależnione jest od postanowienia właściwego sądu ${ }^{52}$.

Biuro Współpracy Międzynarodowej Prokuratury Krajowej przedstawiło 16 marca 2018 r. stanowisko odnoszące się do regulacji zawartych w rozdziałach 62c i 62d Kodeksu postępowania karnego ${ }^{53}$. W dokumencie tym wskazano, że decyzja o wydaniu END w postępowaniu przygotowawczym będzie wyjątkowo wydawana przez sąd w sytuacjach dotyczących np. kontroli i utrwalania treści rozmów telefonicznych oraz utrwalania przy użyciu środków technicznych treści innych rozmów lub przekazów informacji, w tym korespondencji przesyłanej pocztą elektroniczną, czasowego przekazania osoby pozbawionej wolności czy w sytuacjach dotyczących innych czynności, których przeprowadzenie wymaga stosownej decyzji sądu, jak np. przesłuchanie małoletniego w trybie art. 185a k.p.k. czy dostęp do informacji, których uzyskanie na tym etapie postępowania karnego jest uzależnione od wcześniejszej decyzji sądu.

Z przedstawionym powyżej stanowiskiem nie sposób się zgodzić.

W pierwszej kolejności należy wskazać na treść art. $589 \mathrm{w} \$ 1$ k.p.k., który przyznaje prokuratorowi prowadzącemu postępowanie (oraz innym organom w zakresie ich właściwości) wyłączną kompetencję do wydania END na etapie postępowania przygotowawczego. Zgodnie z treścią przywołanego przepisu sąd uzyskuje uprawnienie do wydania europejskiego nakazu

50 M. Kusak, Europejski Nakaz Dochodzeniowy w praktyce...

51 Ibidem.

52 Do tego rodzaju danych należą informacje wskazane w art. 106b ust. 1 ustawy z dnia 29 sierpnia 1997 r. - Prawo bankowe (tekst jedn.: Dz.U. z 2018 r. poz. 2187 ze zm.), tj. informacje stanowiące tajemnicę bankową, do których uzyskania wymagane jest postanowienie właściwego miejscowo sądu okręgowego.

53 Stanowisko Biura Współpracy Międzynarodowej Prokuratury Krajowej z dnia 16 marca 2018 r., PK V WM 520.3.208. 
dochodzeniowego dopiero na etapie postępowania sądowego („sąd, przed którym sprawa się toczy"), a więc nie posiada kompetencji do wydawania tego rodzaju decyzji na etapie postępowania przygotowawczego.

Kolejnym argumentem przemawiającym za zajęciem odmiennego stanowiska jest treść art. 589w $\$ 5$ k.p.k., zgodnie z którym: „Postanowienie o wydaniu END dotyczącego dowodu, którego dopuszczenie, uzyskanie lub przeprowadzenie wymaga wydania postanowienia, zastępuje to postanowienie”, a ponadto $₫ 4$ przytoczonego artykułu, który stanowi: „Postanowienie o wydaniu END dotyczącego kontroli i utrwalania treści rozmów telefonicznych oraz utrwalania przy użyciu środków technicznych treści innych rozmów lub przekazów informacji, w tym korespondencji przesyłanej pocztą elektroniczną, zastępuje postanowienie, o którym mowa w art. $237 \$ 1$ k.p.k. Przepisy rozdziału 26 stosuje się odpowiednio" ${ }^{\prime 54}$. Wskazane uregulowania nie wyłączają więc uprawnienia prokuratora do wydania europejskiego nakazu dochodzeniowego w odniesieniu do tych czynności dowodowych, których dopuszczenie, uzyskanie lub przeprowadzenie wymaga wydania postanowienia, nawet jeśli uprawnienie do wydania takiego postanowienia w podobnej sprawie krajowej posiadałby wyłącznie sąd.

Wreszcie należy wskazać na art. 9 dyrektywy END, zgodnie z którym organ wykonujący uznaje END przekazany zgodnie z dyrektywą, nie wymagając przy tym dopełnienia żadnych dodatkowych formalności, oraz zapewnia jego wykonanie w takim samym trybie i w taki sam sposób, jak w przypadku zarząazenia przeprowadzenia danej czynności dochodzeniowej przez organ państwa wykonującego, a więc na podstawie przepisów obowiązujących w państwie wykonania, które regulują przeprowadzenie żądanej czynności. Zgodnie z przytoczonym przepisem organ wykonujący dopełnia jednak formalności i procedur wyraźnie wskazanych przez organ wydający, o ile dyrektywa END nie stanowi inaczej i pod warunkiem, że takie formalności oraz procedury nie są sprzeczne z podstawowymi zasadami prawa państwa wykonującego.

Wynika z tego jednoznacznie, że organ wykonujący END przeprowadza żądaną czynność dochodzeniową w oparciu o przepisy prawne państwa wykonującego, które regulują przeprowadzenie danej czynności dochodzeniowej, a nie na podstawie prawa państwa wydającego END. W związku z tym zachowanie jakiejś szczególnej procedury związanej z samym tyl-

54 Zgodnie z treścią art. $237 \$ 1$ k.p.k.: „Po wszczęciu postępowania sąd na wniosek prokuratora może zarządzić kontrolę i utrwalanie treści rozmów telefonicznych w celu wykrycia i uzyskania dowodów dla toczącego się postępowania lub zapobieżenia popełnieniu nowego przestępstwa" - wyróżnienie A.K. Odpowiednie stosowanie przepisów zamieszczonych w rozdziale 26 Kodeksu w przypadku END dotyczącego takiej czynności oznacza m.in. dopuszczalność zaskarżenia postanowienia o wydaniu END zgodnie z trybem przewidzianym w art. 240 k.p.k., a także dopuszczalność zastosowania takiej kontroli wyłącznie po spełnieniu warunków wskazanych w tym rozdziale, tak: B. Augustyniak, Kodeks postępowania karnego. Komentarz aktualizowany, LEX nr 10834, komentarz do art. 589w. 
ko wydaniem postanowienia warunkującego dopuszczenie, uzyskanie lub przeprowadzenie określonego dowodu w postępowaniu przygotowawczym w podobnej sprawie krajowej w przypadku wydania END dotyczącego takiej czynności nie ma normatywnego uzasadnienia. Podstawy takiej nie stanowią ani przepisy omawianej dyrektywy, ani cytowany wyżej art. 589w k.p.k., a w szczególności art. 589w $\$ 5$ k.p.k. Należy więc bezspornie przyjąć, że organem właściwym do wydania END na etapie postępowania przygotowawczego jest prokurator prowadzący postępowanie oraz inne organy, które zgodnie z obowiązującymi przepisami mogą prowadzić postępowanie lub też może zostać im powierzone prowadzenie takiego postępowania. Trzeba jednak pamiętać, że wydanie END przez inny organ wymaga zatwierdzenia przez prokuratora.

Pewnego rodzaju wyjątkiem od powyższej zasady jest kwestia dotycząca zatwierdzenia europejskiego nakazu dochodzeniowego wydanego w przypadku wspomnianego wyżej prowadzenia czynności operacyjno-rozpoznawczych na podstawie odrębnych przepisów (np. ustawy o Policji czy ustawy o Agencji Bezpieczeństwa Wewnętrznego oraz Agencji Wywia$\mathrm{du})^{55}$. Został on wskazany wprost $\mathrm{w}$ ustawie, bowiem zgodnie $\mathrm{z}$ art. $589 \mathrm{w}$ $\$ 7$ k.p.k. organem uprawnionym do wydania nakazu w takim przypadku jest organ prowadzący te czynności, jednakże wymaga on zatwierdzenia przez prokuratora właściwego na podstawie odrębnych przepisów, a jeśli dopuszczenie, uzyskanie lub przeprowadzenie takiego dowodu jest zastrzeżone do właściwości sądu, to wówczas zatwierdzenia przez sąd właściwy na podstawie odrębnych przepisów ${ }^{56}$.

\section{Zakończenie}

W świetle powyższych uwag europejski nakaz dochodzeniowy stanowi skuteczny środek współpracy w sprawach karnych w Unii Europejskiej w zakresie transgranicznego gromadzenia materiału dowodowego. To kompleksowe rozwiązanie jest konsekwencją zmian organizacyjnych i strukturalnych samej UE, bowiem zastąpiło niekompletne, rozdrobnione uregulowania w tym zakresie. W stosunku do poprzednich instrumentów dotyczących pomocy prawnej i gromadzenia dowodów stanowi ono istotny krok w kierunku ułatwienia i przyspieszenia pozyskiwania dowodów tran-

55 Ibidem.

56 Jako przykład czynności wymagającej zatwierdzenia przez sąd należy wskazać zarządzenie kontroli operacyjnej na podstawie art. 19 ust. 1 ustawy z dnia 6 kwietnia 1990 r. o Policji (tekst jedn.: Dz.U. z 2019 r. poz. 161 ze zm.), zgodnie z którym przy wykonywaniu czynności operacyjno-rozpoznawczych, podejmowanych przez Policję w celu zapobieżenia, wykrycia, ustalenia sprawców, a także uzyskania i utrwalenia dowodów przestępstw określonych $\mathrm{w}$ tym artykule sąd okręgowy może zarządzić w drodze postanowienia kontrolę operacyjną na pisemny wniosek uprawnionych organów wskazanych w tym przepisie. 
sgranicznych. Prace nad rozwiązaniem tego problemu toczą się od początku objęcia politykami unijnymi współpracy sądowej w sprawach karnych. Mają one charakter rozwojowy, uwzględniający procesy zmian w otoczeniu społeczno-kryminalnym. Nie można zatem wykluczyć, że przedstawiony środek zostanie w przyszłości zastąpiony innym, który odpowiadać będzie nowym oczekiwaniom.

Opisywane narzędzie stosowane jest w celu wezwania właściwych organów państwa wykonującego END do przeprowadzenia na jego terytorium jednej lub więcej określonych czynności dochodzeniowych służących gromadzeniu materiału dowodowego na każdym etapie postępowania karnego. Jego przedmiotem może być - co do zasady - każda czynność dochodzeniowa. Dyrektywa END ze swojego zakresu obowiązywania wyłączyła obserwację transgraniczną, utworzenie wspólnych zespołów dochodzeniowo-śledczych oraz gromadzenie materiału dowodowego w ramach takich zespołów. Europejski nakaz dochodzeniowy ma zatem wymiar horyzontalny, ponieważ dotyczy wszystkich czynności dochodzeniowych mających na celu gromadzenie materiału dowodowego.

W dyrektywie END określone zostały przesłanki wydania europejskiego nakazu dochodzeniowego. Omawiany instrument może być wydany jedynie wtedy, gdy jest niezbędny dla osiągnięcia celów postępowania, a także względem nich proporcjonalny. Możliwość zastosowania europejskiego nakazu dochodzeniowego uwarunkowana jest również wymogiem poszanowania praw przysługujących podejrzanemu i oskarżanemu w postępowaniu karnym. Warunkiem wydania tego środka jest także dopuszczalność przeprowadzenia żądanej czynności dochodzeniowej w jurysdykcji organu wydającego END w toku podobnej sprawy karnej. Obowiązek oceny spełnienia tych przesłanek należy do organu wydającego. W przypadku uznania, że warunki zostały spełnione, organ wydający europejski nakaz dochodzeniowy przekazuje go - co do zasady - bezpośrednio organowi wykonującemu. Dyrektywa END przyznaje państwom członkowskim uprawnienie do wyznaczenia organu centralnego, którego zadaniem jest pełnienie funkcji pomocniczych, $w$ tym przekazywanie i odbiór europejskich nakazów dochodzeniowych oraz prowadzenie dalszej korespondencji urzędowej dotyczącej END. Przekazanie tego środka do właściwego organu wykonującego następuje w każdy możliwy i odpowiedni sposób, również za pośrednictwem systemu telekomunikacyjnego Europejskiej Sieci Sądowej.

Europejski nakaz dochodzeniowy został wprowadzony do polskiego porządku prawnego na podstawie ustawy z dnia 10 stycznia $2018 \mathrm{r}$. o zmianie ustawy - Kodeks postępowania karnego oraz niektórych innych ustaw ${ }^{57}$. Największe problemy praktyczne dotyczące END związane są z procesem

57 Ustawa z dnia 10 stycznia 2018 r. o zmianie ustawy - Kodeks postępowania karnego oraz niektórych innych ustaw, Dz.U. poz. 201. Ustawa weszła w życie w dniu 8 lutego $2018 \mathrm{r}$. 
jego wydawania w toku postępowania przygotowawczego i odnoszą się do dowodów, których uzyskanie, dopuszczenie lub przeprowadzenie na tym etapie postępowania karnego wymaga uprzedniej decyzji sądu. Poczynione w niniejszym opracowaniu rozważania pozwalają na wyciągnięcie wnios$\mathrm{ku}$, że organem uprawnionym do wydania europejskiego nakazu dochodzeniowego na etapie postępowania przygotowawczego jest prokurator prowadzący postępowanie oraz inne organy, które zgodnie z obowiązującymi przepisami mogą prowadzić postępowanie lub też może zostać im powierzone prowadzenie takiego postępowania (z zastrzeżeniem obowiązku zatwierdzenia takiego END przez prokuratora), nawet w odniesieniu do czynności dochodzeniowych, które w podobnej sprawie krajowej wymagałyby uprzedniej decyzji właściwego sądu.

\section{Bibliografia}

Augustyniak B., Kodeks postępowania karnego. Komentarz aktualizowany, LEX nr 10834.

Buczma S.R., Kierzynka R., Europejski nakaz dochodzeniowy. Nowy model współpracy $w$ sprawach karnych $w$ Unii Europejskiej, Warszawa 2018.

Gajda A., Polityka bezpieczeństwa wewnętrznego Unii Europejskiej, „Studia z Polityki Publicznej" 2015, nr 3.

Janicz M. [w:] Kodeks postepowania karnego. Komentarz, LEX nr 10800.

Kawka I., Kompetencje Unii Europejskiej i państw członkowskich $w$ dziedzinie bezpieczeństwa wewnętrznego, „Annales Universitatis Paedagogicae Cracoviensis”, Studia Politologica VII. Bezpieczeństwo wewnętrzne państwa 2012, nr 119.

Krzysztofiuk G., Europejski Nakaz Dochodzeniowy, LEX nr 277538.

Kusak M., Dowody zagraniczne. Dopuszczalność w polskim procesie karnym. Przewodnik $z$ wzorami, LEX nr 347301.

Kusak M., Europejski nakaz dochodzeniowy - przełom $w$ dziedzinie europejskiego ścigania karnego?, „Ruch Prawniczy, Ekonomiczny i Socjologiczny” 2012, z. 4.

Kusak M., Europejski nakaz dochodzeniowy w praktyce, LEX nr 335832.

Metodyka pracy $w$ sprawach karnych ze stosunków międzynarodowych, J. Gemra (red.), Warszawa 2013.

Rams M., Specyfika wykładni prawa karnego w kontekście brzmienia i celu prawa Unii Europejskiej, LEX nr 296400.

\section{Akty prawne i dokumenty urzędowe}

Traktat o Unii Europejskiej, wersja skonsolidowana Dz.Urz. UE z 2016 r. C 202, s. 13.

Traktat o funkcjonowaniu Unii Europejskiej, wersja skonsolidowana Dz.Urz. UE z 2016 r. C 202.

Europejska konwencja o pomocy prawnej w sprawach karnych z 20 kwietnia 1959 r., Dz.U. z 1999 r. Nr 76, poz. 854 ze zm.

Konwencja wykonawcza do układu z Schengen z dnia 14 czerwca 1985 r. między Rządami Państw Unii Gospodarczej Beneluksu, Republiki Federalnej Nie- 
miec oraz Republiki Francuskiej w sprawie stopniowego znoszenia kontroli na wspólnych granicach, Dz.Urz. WE z 2000 r. L 239, s. 19, ze zm.

Konwencja o wzajemnej pomocy w sprawach karnych między państwami członkowskimi Unii Europejskiej, Dz.U. z 1998 r. Nr 141, poz. 913 ze zm.

Konwencja ustanowiona przez Radę zgodnie z art. 34 Traktatu o Unii Europejskiej o pomocy prawnej w sprawach karnych między państwami członkowskimi Unii Europejskiej, Dz.Urz. UE z 2000 r. L 197, s. 3, ze zm.

Dyrektywa Parlamentu Europejskiego i Rady 2010/64/UE z dnia 20 października 2010 r. w sprawie prawa do tłumaczenia ustnego i tłumaczenia pisemnego w postępowaniu karnym, Dz.Urz. UE L 280, s. 1.

Dyrektywa Parlamentu Europejskiego i Rady 2012/13/UE z dnia 22 maja 2012 r. w sprawie prawa do informacji w postępowaniu karnym, Dz.Urz. UE L 142, s. 1.

Dyrektywa Parlamentu Europejskiego i Rady 2013/48/UE z dnia 22 października 2013 r. w sprawie prawa dostępu do adwokata w postępowaniu karnym i w postępowaniu dotyczącym europejskiego nakazu aresztowania oraz w sprawie prawa do poinformowania osoby trzeciej o pozbawieniu wolności i prawa do porozumiewania się z osobami trzecimi i organami konsularnymi w czasie pozbawienia wolności, Dz.Urz. UE L 294, s. 1.

Dyrektywa Parlamentu Europejskiego i Rady nr 2014/41/UE z dnia 3 kwietnia 2014 r. w sprawie europejskiego nakazu dochodzeniowego w sprawach karnych, Dz.Urz. UE L 130, s. 1, ze zm.

Rozporządzenie Parlamentu Europejskiego i Rady (UE) nr 2016/95 z dnia 20 stycznia 2016 r. w sprawie uchylenia niektórych aktów w dziedzinie współpracy policyjnej i współpracy wymiarów sprawiedliwości w sprawach karnych, Dz.Urz. UE L 26, s. 9.

Decyzja ramowa Rady z dnia 13 czerwca 2002 r. w sprawie wspólnych zespołów dochodzeniowo-śledczych (2002/465/WSiSW), Dz.Urz. UE L 162, s. 1.

Decyzja ramowa Rady 2003/577/WSiSW z dnia 22 lipca 2003 r. w sprawie wykonania w Unii Europejskiej postanowień o zabezpieczeniu mienia i środków dowodowych, Dz.Urz. UE L 196, s. 45.

Decyzja ramowa Rady 2008/978/WSiSW z dnia 18 grudnia 2008 r. w sprawie europejskiego nakazu dowodowego dotyczącego przedmiotów, dokumentów i danych, które mają zostać wykorzystane w postępowaniach w sprawach karnych, Dz.Urz. UE L 350, s. 72.

Komunikat Komisji do Parlamentu Europejskiego i Rady: Przestrzeń wolności, bezpieczeństwa i sprawiedliwości w służbie obywateli, COM (2009) 262 wersja ostateczna, https://eur-lex.europa.eu/legal-content/PL/TXT/?uri=CELEX \%3A52009DC0262.

Ustawa z dnia 6 kwietnia 1990 r. o Policji, tekst jedn.: Dz.U. z 2019 r. poz. 161 ze zm.

Ustawa z dnia 6 czerwca 1997 r. - Kodeks postępowania karnego, tekst jedn.: Dz.U. z 2018 r. poz. 1987 ze zm.

Ustawa z dnia 10 września 1999 r. - Kodeks karny skarbowy, tekst jedn.: Dz.U. z 2018 poz. 1958 ze zm.

Ustawa z dnia 29 sierpnia 1997 r. - Prawo bankowe, tekst jedn.: Dz.U. z 2018 r. poz. $2187 \mathrm{ze}$ zm.

Ustawa z dnia 10 stycznia 2018 r. o zmianie ustawy - Kodeks postępowania karnego oraz niektórych innych ustaw, Dz.U. poz. 201. 
Posiedzenie Rady Europejskiej w dniach 15-16 października 1999 r. w Tampere, Konkluzje Prezydencji, https://www.consilium.europa.eu/media/21059/tampere-european-council-presidency-conclusions.pdf.

Program działań na rzecz wdrożenia zasady wzajemnego uznawania orzeczeń w sprawach karnych, Dz.Urz. UE z 2001 r. C 12.

Program Haski: wzmacnianie wolności, bezpieczeństwa i sprawiedliwości w Unii Europejskiej, Dz.Urz. UE z 2005 r. C 53, s. 1.

Procedura 2010/0817/COD przyjęcia dyrektywy nr 2014/41/UE, https://eur-lex. europa.eu/legal-content/PL/HIS/?uri=CELEX:32014L0041.

Stanowisko Biura Współpracy Międzynarodowej Prokuratury Krajowej z dnia 16 marca 2018 r., PK V WM 520.3.208.

Zielona Księga z dnia 11 listopada 2009 r. w sprawie wzajemnego udostępniania przez państwa członkowskie materiału dowodowego w sprawach karnych oraz zapewnienia jego dopuszczalności, KOM (2009) 624 wersja ostateczna, https://eur-lex.europa.eu/LexUriServ/LexUriServ.do?uri=COM:2009:0624: FIN:PL:PDF.

Streszczenie

W niniejszym opracowaniu omówiona została istota, cel i przedmiot europejskiego nakazu dochodzeniowego, poruszono również zagadnienia związane z wydaniem nakazu oraz jego przekazaniem państwu wykonującemu. W artykule przedstawiono genezę tego instrumentu oraz porównanie do dotychczasowych uregulowań dotyczących współpracy w sprawach karnych w Unii Europejskiej w zakresie transgranicznego gromadzenia materiału dowodowego. Autorka poświęciła także uwagę problemom praktycznym związanym $\mathrm{z}$ wydaniem europejskiego nakazu dochodzeniowego $\mathrm{w}$ toku postępowania przygotowawczego.

Słowa kluczowe: europejski nakaz dochodzeniowy, postępowanie przygotowawcze, transgraniczne gromadzenie dowodów

\title{
European Investigation Order as a Comprehensive Instrument of Cooperation in Criminal Matters in the European Union
}

\begin{abstract}
This article discusses the essence, objective and object of the European Investigation Order (EIO). The author also focuses on the EIO issuance and how the Order is transferred to the executing state. The article discusses the origins of the instrument and compares it with previous regulations concerning cooperation in criminal matters in the European Union as regards transborder collection of evidence. The author also focuses on practical issues related to the EIO issuance in the course of preliminary proceedings.
\end{abstract}

Keywords: European Investigation Order, preliminary proceedings, transborder collection of evidence 